\title{
A 13-year review of plastic and hand surgery research funding by the National Institute of Health Research.
}

\author{
Grant S. Nolan1
}

Abhilash Jain 1,2

1. Department of Plastic \& Reconstruction Surgery, St Mary's Hospital, Imperial College Healthcare NHS Trust, London, W2 1NY

2. Nuffield Department of Orthopaedics, Rheumatology and Musculoskeletal Sciences, University of Oxford, Roosevelt Drive, Oxford, OX3 7LD

For editorial correspondence:

Grant Nolan,

377c Fulham Palace Road, London, SW6 6TA

grant.nolan@nhs.net or grantnolan@me.com

07890962564

For author correspondence:

Abhilash Jain,

Nuffield Department of Orthopaedics, Rheumatology and Musculoskeletal Sciences, University of Oxford, Roosevelt Drive, Oxford OX3 7FY, UK. 


\section{Summary}

\section{Introduction}

From 2013 onwards there were a number of national initiatives to improve the quality and quantity of plastic and hand surgery research; the Royal College of Surgeon Clinical Trials Initiative; creation of the Reconstructive Surgery Trials Network, appointment of research leads; national research training and association led research projects. We aimed to establish what impact these had on National Institute of Health Research (NIHR) grant success.

\section{Methods}

Two independent reviewers screened all 3642 awarded grants in the NIHR Open Database (20062019) and NIHR website funding entries against a priori list of definitions of plastic surgery and hand surgery involvement and established a list of grants relevant to plastic and hand surgery and the value of these grants. We compared outputs prior to the start of the 2013 initiatives to those after.

\section{Results}

Prior to 2013 there were four NIHR grants in hand surgery and none in plastic surgery totalling f2.6m. After 2013 there were 22 NIHR grants (nine plastic and 13 hand surgery) totalling $£ 15.2 \mathrm{~m}$.

\section{Conclusion}

There has been an almost six fold increase in the number of successful NIHR grants resulting in a similar increase in funding from the NIHR since 2013. Proportional to total number of NIHR grants awarded this represents an increase from $0.6 \%$ in 2010 to $1.6 \%$ in 2016 . The reason for this is multifactorial but $30 \%$ of this increase seems related to the national initiatives to support surgical research started in 2013. 
Keywords (4-6)

Mesh headings:

- Surgery, Plastic

- Burns

- Surgery, Hand

- Randomized Controlled Trial

- Research Support as Topic

- National Institute of Health Research 
Dear Sir

In 2012 the Royal College of Surgeons of England (RCS) launched a clinical trials initiative to increase the quantity and quality of clinical surgical research. The British Association of Plastic, Reconstructive and Aesthetic Surgeons (BAPRAS) and British Society for Surgery of the Hand (BSSH) supported the initiative by appointing a Surgical Specialty Lead and the development of the Reconstructive Surgery Trials Network (RSTN) in 2013. The RSTN enables access to methodological support from six United Kingdom (UK) surgical trials centres and established the infrastructure to deliver multicentre studies based on the UK trainee collaborative model. Subsequently, the BSSH funded a Clinical Professor of Hand Surgery at the University of Nottingham who set up the Centre for Evidence Based Hand Surgery and Hand Fracture Research Group. In 2017 the BSSH funded James Lind Alliance (JLA) Priority Setting Partnership on hand and wrist conditions published their top 10 research priorities ${ }^{1}$. Simultaneously BAPRAS launched a modified Delphi research prioritization exercise that published the associations top 10 areas of research focus ${ }^{2}$. In addition there has been increased RCS support for research training and since 2013 the BSSH and BAPRAS have established training sessions at their scientific meetings and an annual RTSN research day. The National Institute for Health Research (NIHR) is the nation's largest funder of health and care research. It is primarily centred on England, yet works closely with other administrators around the UK. Given the increase in clinical research support in plastic and hand surgery, the aim of this study was to document the success of obtaining NIHR grants for plastic and hand surgery research.

Two reviewers independently screened all 3642 awarded grants in the NIHR Open Database (20062019) ${ }^{3}$ and NIHR website funding entries ${ }^{4,5}$ against a priori list of definitions of plastic and hand (including wrist) surgery to establish a shortlist (figure 1, table 1). All shortlisted grant abstracts were reviewed and consensus made to if the grant was truly relevant to plastic and hand surgery. Of those relevant, the background of each grant's principle investigator was established to identify if 
the grant had significant engagement of a plastic or hand surgeon or was run by another specialty (figure 1).

In the 7 years prior to 2013 there were four hand surgery funded NIHR grants totalling $f 2.6 \mathrm{~m}$. In the 6 years after 2013 there were $22 \mathrm{NIHR}$ grants totalling $f 15.2 \mathrm{~m}$ of which 13 were in hand surgery and nine in plastic surgery (table 1). The total NIHR grant investment in plastic ( $₫ 5.4 \mathrm{~m})$ and hand surgery $(£ 12.4 \mathrm{~m})$ represents approximately $0.5 \%$ of the $£ 2.5$ billion awarded overall. Grants awarded to all NIHR programmes and all specialties have increased from 20 grants in 2006 to approximately 350 per year from 2010 onward. Recently plastic and hand surgery have been awarded a higher proportion of these grants increasing from $0.5 \%$ and $0.7 \%$ in 2009 and 2010 respectively, to $1.4 \%$ and $1.6 \%$ in 2015 and 2016 respectively.

Establishing a national clinical research culture takes time and clearly this increase has not been solely down to the initiatives described. However, since 2015 there have been seven RSTN and Nottingham supported projects awarded NIHR grants. Furthermore, the BSSH JLA project has supported an NIHR Health Technology Assessment (HTA) commissioned call in digital nerve repair and at least two further NIHR HTA hand surgery applications; the outcomes of which will be know later in 2019. Support from the trials units has been crucial and may not have been as accessible had it not been for the RCS investment in them.

An observation was that the 24 grants related to plastic and hand surgery were run by other specialties totalled $f 19.0 \mathrm{~m}$. These grants covered wound healing, cleft surgery, skin cancer, lower limb trauma, tissue engineering and breast surgery (figure 1). Funding for these grants was higher than that achieved by plastic and hand surgeons and therefore represents areas that plastic and hand surgeons could lead on in the future.

Our data does not show unsuccessful NIHR applications, which are considerable, given the high attrition rate of the NIHR awards process. A limitation of our study is that we only looked at grants 
secured from the NIHR (as they are the largest source of clinical research funding) but there are other funders that support research as well as industry funding. Furthermore, while our study looked only at successful NIHR grant applications, smaller studies do get NIHR portfolio support through the Clinical Research Network as well as NIHR funded Academic Clinical Fellow and Lecturer positions.

There is still a long way to go but with the support of national bodies, plastic and hand surgeons in the UK have demonstrated that a difference can be made to the quality and quantity of clinical research.

\section{Acknowledgements}

The authors would like to thank the Royal College of Surgeons of England, the British Association of Plastic, Reconstructive and Aesthetic Surgeons (BAPRAS), the British Society for Surgery of the Hand (BSSH) and the Reconstructive Surgery Trials Network (RSTN) for their support.

\section{Conflict of interest}

Abhilash Jain is the Royal College of Surgeons Surgical Specialty Lead for plastic and hand surgery, founded and leads the Reconstructive Surgery Trials Network and was a member of both the BAPRAS Delphi project and the BSSH James Lind Alliance Priority Setting Partnership teams.

\section{Sources of funding}

None. 


\section{References}

1. The British Society for Surgery of the Hand. BSSH James Lind Alliance priority setting partnership. 2017.

2. Henderson J, Reid A, Jain A. Use of a modified BAPRAS Delphi process for research priority setting in Plastic Surgery in the UK. J Plast Reconstr Aesthet Surg 2018: 71: 1679-81.

3. National Institue for Health Research. NIHR Open Data - Funded Portfolio. 2018.

4. National Institue for Health Research. Funding decisions. 2018.

5. National Institute for Health Research. Funding Boards. 2018. 

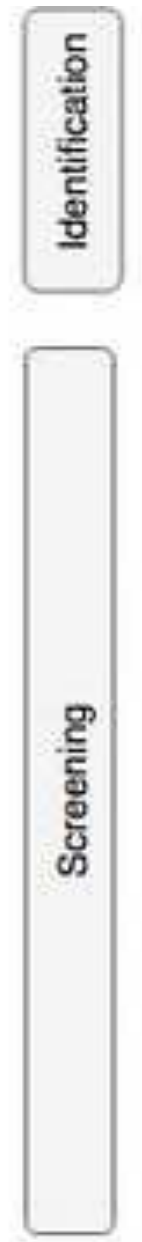

\section{Records excluded}

$(n=3578)$

- Priar to NiHR creation $(n=5)$

- Screened as not relevant $(n=3573$ )

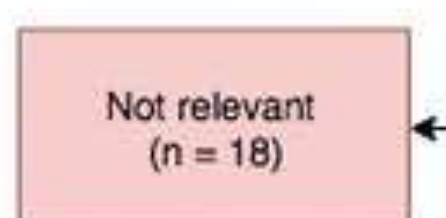

- Pressure sore preventon trals $(n=5)$

- Upper limb spasticity atter stroke $(n=2)$

- Oral heath $(n=2)$

- Primary care studes $(n=1)$

- Imaging studios $(n=1)$

- Medical treatment of celiulits $(n=1)$

- Other $(n=6)$

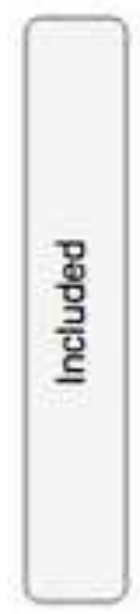

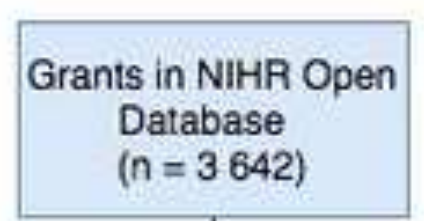

।

Titles reviewed

independently by

two authors

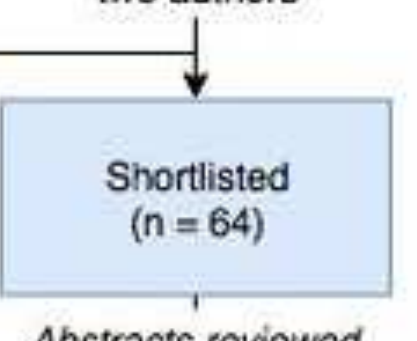

Abstracts reviewed

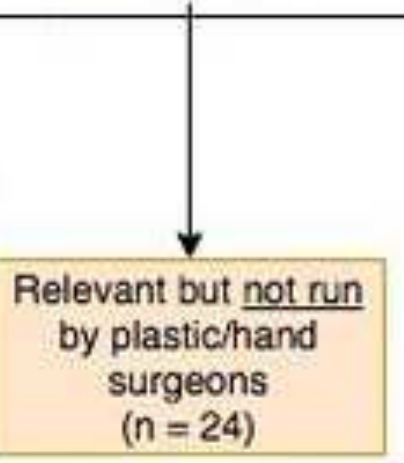

- Nerve related trials $(n=5)$

- Wound heaing triais $(n=4)$

- Lower limb $(n=3$;

- Breast $(n=3)$

- Hand $(n=2)$

- Clett $(n=2)$

- Skin cancer $(n=2)$

- Other $(n=3)$

\section{Additional grants identified $(n=4)$}

- NIHA board funding minutes $(n=2)$

- NIHR Global Studies $(n=1)$

- $\operatorname{RSTN}(n=1)$

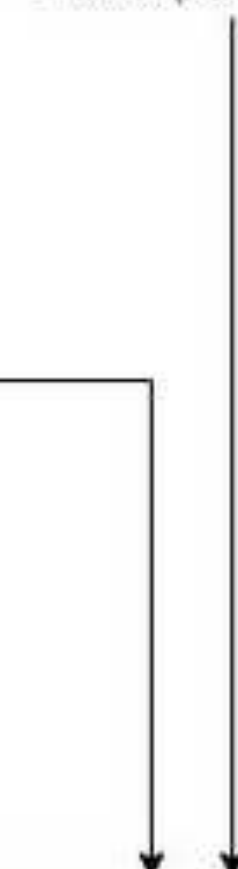

\section{Relevant and run by} plastic/hand surgeons ( $n=26$ )

See table 1
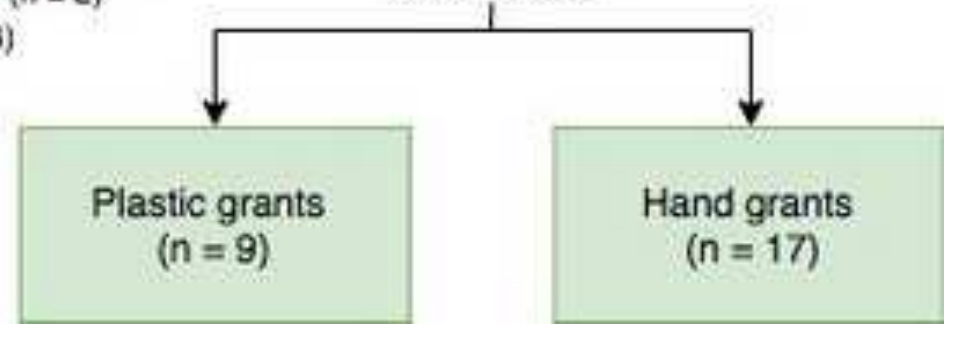


\section{Figure and Table legends}

Figure 1: Flow diagram of methodology for identifying NIHR funded grants in plastic and hand surgery. The full details of plastic and hand grants included are outlined in table 1.

Table 1: NIHR grants in plastic and hand surgery. All the grants listed had significant engagement of a plastic or hand surgeon. Abbreviations used are HTA = Health Technology Assessment, RfPB = Research for Patient Benefit, $\mathrm{i} 4 \mathrm{i}=$ Invention for Innovation, IAT = Integrated Academic Training Programme. Individual grant figures rounded to nearest $£ 100$ and yearly total rounded to nearest $£ 100,000$. 
Table 1.

\begin{tabular}{|c|c|c|c|c|c|c|}
\hline \multirow[b]{2}{*}{ Year } & \multirow[b]{2}{*}{ NIHR grant } & \multicolumn{2}{|c|}{ Type of project } & \multirow{2}{*}{$\begin{array}{l}\text { Type of } \\
\text { grant }\end{array}$} & \multirow{2}{*}{$\begin{array}{l}\text { Money } \\
\text { awarded }\end{array}$} & \multirow[b]{2}{*}{ Total } \\
\hline & & Plastic & Hands & & & \\
\hline 2006 & $\begin{array}{l}\text { Genetics of Dupuytren's } \\
\text { disease (Manchester) }\end{array}$ & & $x$ & IAT & $£ 727100$ & $\begin{array}{l}n=1 \\
f 0.7 m\end{array}$ \\
\hline 2009 & $\begin{array}{l}\text { Recovery of sensory/motor } \\
\text { function post carpal tunnel } \\
\text { (Norwich) }\end{array}$ & & $x$ & $\begin{array}{c}\text { NIHR } \\
\text { Fellowship }\end{array}$ & $£ 378300$ & $\begin{array}{l}n=1 \\
£ 0.4 m\end{array}$ \\
\hline \multirow[t]{2}{*}{2010} & $\begin{array}{l}\text { RCT in K-wires vs. locking } \\
\text { plate distal radius fracture } \\
\text { (Warwick) }\end{array}$ & & $x$ & HTA & $£ 1300500$ & \multirow[t]{2}{*}{$\begin{array}{l}\mathrm{n}=2 \\
\mathrm{f} 1.5 \mathrm{~m}\end{array}$} \\
\hline & $\begin{array}{l}\text { DRIFT - Distal Radius Internal } \\
\text { Fixation Trial (North Wales) }\end{array}$ & & $x$ & RfPB & $f 236400$ & \\
\hline \multirow[t]{3}{*}{2013} & $\begin{array}{l}\text { Improving management of } \\
\text { carpal tunnel (Leicester) }\end{array}$ & & $x$ & $\begin{array}{c}\text { NIHR } \\
\text { Fellowship }\end{array}$ & $f 542400$ & \multirow[t]{3}{*}{$\begin{array}{l}n=3 \\
f 2.9 m\end{array}$} \\
\hline & $\begin{array}{l}\text { SWIFTT - cast vs. fixation in } \\
\text { scaphoid fracture trial } \\
\text { (Leicester) }\end{array}$ & & $x$ & HTA & f2 284700 & \\
\hline & $\begin{array}{l}\text { In-Practice Fellowship on } \\
\text { carpal tunnel (Keele) }\end{array}$ & & $x$ & IAT & $f 111000$ & \\
\hline \multirow[t]{2}{*}{2014} & $\begin{array}{l}\text { Nerve conduit with novel } \\
\text { polymer (Manchester) }\end{array}$ & $x$ & & i4i & $f 818800$ & \multirow[t]{2}{*}{$\begin{array}{l}n=2 \\
f 1.2 m\end{array}$} \\
\hline & Garments for burns scars & $x$ & & HTA & $£ 417900$ & \\
\hline
\end{tabular}




\begin{tabular}{|c|c|c|c|c|c|c|}
\hline & (Birmingham) & & & & & \\
\hline \multirow[t]{5}{*}{2015} & $\begin{array}{l}\text { DRAFFT - Distal radius } \\
\text { fixation trial (Oxford) }\end{array}$ & & $x$ & HTA & $f 66000$ & \multirow[t]{5}{*}{$\begin{array}{l}n=5 \\
f 1.0 m\end{array}$} \\
\hline & $\begin{array}{l}\text { iBRA - implant breast } \\
\text { reconstruction evaluation } \\
\text { (Bristol) }\end{array}$ & $x$ & & RfPB & f243400 & \\
\hline & $\begin{array}{l}\text { SILKIE - skin grafting in burns } \\
\text { with low friction } \\
\text { environment (Bristol) }\end{array}$ & $x$ & & RfPB & $£ 237400$ & \\
\hline & $\begin{array}{l}\text { Needle fasciotomy vs. } \\
\text { limited fasciectomy for } \\
\text { Dupuytren's (Nottingham) }\end{array}$ & & $x$ & RfPB & £259800 & \\
\hline & $\begin{array}{l}\text { Heat to improve wound } \\
\text { healing after breast } \\
\text { reconstruction (London) }\end{array}$ & $x$ & & RfPB & $f 216500$ & \\
\hline \multirow[t]{4}{*}{2016} & $\begin{array}{l}\text { REACTS - returning to work } \\
\text { after carpal tunnel release } \\
\text { (Southampton) }\end{array}$ & & $x$ & $\begin{array}{c}\text { NIHR } \\
\text { Fellowship }\end{array}$ & $£ 284400$ & \multirow[t]{4}{*}{$\begin{array}{l}n=5 \\
£ 4.3 m\end{array}$} \\
\hline & $\begin{array}{l}\text { DRAFFT2 - Distal radius } \\
\text { fixation trial } 2 \text { (Oxford) }\end{array}$ & & $x$ & HTA & f1 248600 & \\
\hline & $\begin{array}{l}\text { Outcomes from common } \\
\text { hand conditions (Oxford) }\end{array}$ & & $x$ & $\begin{array}{c}\text { NIHR } \\
\text { Fellowship }\end{array}$ & f335 200 & \\
\hline & $\begin{array}{l}\text { DISC - Dupuytren's surgery } \\
\text { vs. collagenase RCT } \\
\text { (Leicester) }\end{array}$ & & $x$ & HTA & £1942000 & \\
\hline
\end{tabular}




\begin{tabular}{|c|c|c|c|c|c|c|}
\hline & $\begin{array}{l}\text { COSBY - burns in young } \\
\text { people outcome measures } \\
\text { (Bristol) }\end{array}$ & $x$ & & $\begin{array}{l}\text { NIHR } \\
\text { Fellowship }\end{array}$ & f531300 & \\
\hline \multirow[t]{2}{*}{2017} & $\begin{array}{l}\text { NINJA - Nail bed injury } \\
\text { analysis trial (Oxford) }\end{array}$ & & $x$ & RfPB & f348600 & \multirow[t]{2}{*}{$\begin{array}{l}n=2 \\
f 2.3 m\end{array}$} \\
\hline & $\begin{array}{l}\text { Global health research on } \\
\text { burn trauma (Swansea) }\end{array}$ & $x$ & & Global & f1 997600 & \\
\hline \multirow[t]{5}{*}{2018} & $\begin{array}{l}\text { Decision making in hand } \\
\text { surgery (Oxford) }\end{array}$ & & $x$ & $\begin{array}{l}\text { NIHR } \\
\text { Fellowship }\end{array}$ & f415 400 & \multirow[t]{5}{*}{$\begin{array}{l}n=5 \\
f 3.3 m\end{array}$} \\
\hline & $\begin{array}{l}\text { Sys-Stem - fat transfer for } \\
\text { oro/facial fibrosis is systemic } \\
\text { sclerosis (London) }\end{array}$ & $x$ & & RfPB & $£ 246000$ & \\
\hline & $\begin{array}{l}\text { POINT - proximal phalanx } \\
\text { fracture fixation trial } \\
\text { (Nottingham) }\end{array}$ & & $x$ & HTA & $f 1400000$ & \\
\hline & $\begin{array}{l}\text { THESEUS - Hidradenitis } \\
\text { suppurativa study (Cardiff) }\end{array}$ & $x$ & & HTA & f660 300 & \\
\hline & $\begin{array}{l}\text { MRI for diagnosing traumatic } \\
\text { brachial plexus injuries } \\
\text { (Leeds) }\end{array}$ & & $x$ & $\begin{array}{l}\text { NIHR } \\
\text { Fellowship }\end{array}$ & $f 544600$ & \\
\hline
\end{tabular}

